\title{
Architectural Quality through the Integration of Users' Viewpoints in Architectural Design: Case Study Pouillon's Diar Es Saada
}

\author{
*Tehami Mohamed and Anouche Karima
}

\begin{abstract}
Published online: 31 August 2018
To cite this article: Tehami Mohamed and Anouche Karima (2018). Architectural quality through the integration of users' viewpoints in architectural design: Case study Pouillon's Diar Es Saada. Journal of Construction in Developing Countries, 23(1): 149-175. https://doi.org/10.21315/jcdc2018.23.1.9.
\end{abstract}

To link to this article: https://doi.org/10.21315/jcdc2018.23.1.9

\begin{abstract}
After the Second World War, the housing production processes went through industrialisation in order to deal with the quantity crisis. Since then, the housing quality management has been inspired by the manufacturing industry approaches. Several approaches have been proposed to ensure this quality through the control of the design process. These approaches quantify the quality and make it measurable according to indicators. Consequently, the quality management concerns the building much more, as an industrial product, rather than an architectural object. This problem affects the housing sector more than services buildings. In the 1950s, Fernand Pouillon handled this housing crisis with the construction of housing estates by opting for a quality of the architectural object. This was through a new interpretation of the architectural composition, which takes into account the pedestrian viewpoints (viewing angles). It was inspired by the arrangement principle of the buildings of the Acropolis of Athens. In this paper, the goal is to consider the possibility of a new focus on the architectural quality of housing estates by the integration of the users' viewing angles in the architectural composition. It will be through the analysis of the housing estate in Algeria, "Diar Es Saada" of Pouillon.
\end{abstract}

Keywords: Architectural quality, Architectural composition, Viewing angles, Housing estate, Diar Es Saada, Fernand Pouillon

\section{INTRODUCTION}

In Algeria, with the expansion of the social housing stock and the ever-increasing demand, project managers are dealing with the challenge of finding solutions to ensure a balance between quality and quantity in the housing. To manage the situation, the government establishes requirements for social housing.' The objectives, sought through this consultation, must reflect the will of the project managers to find the best solutions in order to respond qualitatively to a production of housing.

These technical and functional requirements on housing are a strategy part of the realisation of two million dwellings as a political will to improve the architectural quality of social housing in Algeria. Despite these efforts of the government, the result is far from being conclusive. That is why this study will seek to address the issue of the architectural quality of social housing from another viewpoint.

Today, the issue of quality is the centre of the problem related to all areas of production and services. This makes the term quality widely used in literature, and

Université des Sciences et de la Technologie d'Oran Mohamed Boudiaf, USTO-MB, BP 1505, El M'naouer, 31000 Oran, ALGERIA

"Corresponding author: mohamed.tehami@univ-usto.dz 
becomes very ambiguous and seems to obey subjectivity (Biau and Lautier, 2009). Quality sometimes becomes the opposite of quantity, and it is related to the cost of production. This has led to the definition and the use of the term "quality" in the scientific language, and can even be quantified according to the standards set by the discipline concerned. It is often associated with terms that diversify its meaning: "architectural quality", "construction quality", "high environmental quality", "sanitary quality", "quality of life" and etc. (Biau and Lautier, 2009).

For example, in business management, the term "quality" is not used to express a degree of excellence in a comparative sense, nor used in a quantitative sense for technical assessments. The quality of a product or service is influenced by many phases of interdependent activities such as design, production or after-sales service and maintenance (Deeb, 2008).

On the other hand, when architecture and urbanism are concerned, quality is measured by the double dimension of the constructed object as artwork and service; as a service focusing on the use and the technical or social functions offered to its users. While as an artwork, the quality concerns the art value of the object far from any functional dimension. In housing, specifically social housing, quality has an intrinsic relationship with cost. We know that the budget of social housing is limited compared to that of the high standard housing. This means that the quality requirements are not the same in these two different categories. In high standard housing, the cost is less important than the architectural and construction quality required while in social housing, we are always looking for inexpensive initiatives that do not exceed the budget, in the same time, ensure a quality for a decent housing. Therefore, this study on the architectural quality of social housing, proposes a free initiative that can ensure an architectural quality like in the classical Greek buildings, where users viewpoints (view angles) were taken into consideration in the composition principle.

In this research, interest has been focused on Philippe Dehan's reflection, which highlights the difference between architectural quality and the quality of industrial products. This reflection is based on the fact that the architectural overall (le tout architectural) is more than the sum of the different parts (Dehan, 2009), and that housing cannot be reduced to an economic and technical product (Conrad, 2009). Thus, the problematic of this research concerns the architectural quality of social housing as an architectural object rather than an industrial product.

Hence, the goal is to consider the possibility of a new focus on the architectural quality of housing through the integration of the users' viewpoints (viewing angles) in the design process. The complex Diar Es Saada of Pouillon is the case study in this paper. Fernand Pouillon (1912-1986) is an architect and an urban planner who succeeded in the 1950s in handling the housing crisis through the construction of housing estates based on a new vision of the architectural quality.

To meet our goal, the paper is organised with the first step contains a literature review of researches and developed approaches on the quality issue. Then, a reflection will be developed through the analysis of the case study of Diar Es Saada. In this step, the paper will propose the applicability of the viewing angles' approach in the architectural composition of the case study. Then, a discussion will permit to show the novelty proposed of the viewing angles' approach compared with the other quality approaches. Finally, the conclusion will present an interpretation of the research results, as well as recommendations, limits, and perspectives for the application of this approach. 


\section{LITERATURE REVIEW}

Numerous studies have tried to deal with the issue of architectural quality. Each of them undertakes a different approach to try to come out with guidelines and recommendations for the architect. Studies that pose as problematic the impact of the regulations resulting from planning documents on architectural quality as well as the comfort of users (Wellhoff and Perignon, 2010). While other researchworks prefer to reach the quality by identifying the different parametres involved in the "measurement" of this quality, which are based on evaluation methods and approaches that try to quantify this quality through indicators. This approach of quality measurement dates from the industrial period with the increase of production in the automotive industry. It was essential to control the quality of mass production by inventing the management of quality. After the Second World War, the need to build much more quickly led to the industrialisation of its processes.

The question of architectural quality does not date from today, so the approaches and the methods which were developed to improve it are the result of the evolution of the quality concept.

Going back to the 19th century, the research for architectural quality in France meant choosing a "good architect" for a specific program (Dehan, 2016: 70). For example in the city of Rennes, one spoke of architecte de fonction. After the Second World War, and with the industrialisation of construction in France, more interests were in technical quality by setting standards. These prescriptions were useful in the technical plan, but they did not concern the architectural design and the space planning (Dehan, 2016). To overcome this problem, the government set up the policy of the models from year 1968, which allowed ensuring the quantity as well as the control of the production cost. This policy consists in systematically reproducing models validated by the government throughout the territory without any modification. It was quickly challenged by the fact that the role of the architect was narrowed to a simple designer dominated by the construction company. Françoise Choay, commissioned by the government, formed a team with Christopher Alexander, Jacques Boulet and Philippe Gresset to make an assessment seven years after the launch of the model policy (Dehan, 2016: 73).

At the end of the year 1980s, the ISO 9001 quality standard was created. This standard prompts the publication of standards and methodological manuals on quality. Quality management and control of the production process have been the centre of interest in the quality research. Lessons have been learned from the manufacturing industry; Froman illustrated this in his Manuel de qualite (Froman, 1998). When on the other hand in the United Kingdom (UK), lessons have been learned from the literature "lean production and Japanese approaches to quality management", it concerns mostly measures of the quality, time and cost of production (Gann, Salter and Whyte, 2003). The United States, Australia and Japan had similar concerns. For them, improving the quality and value of the building consists of evolving the design process (Gann, Salter and Whyte, 2003).

The approaches developed in the late 1990s and early 2000s aimed at controlling and improving the production process in order to improve the quality of construction. These approaches have given satisfactory results in terms of quantity, respect of the deadline and even in terms of the technical quality of the realisation. However, these approaches neglected the design quality in relation to the space and the architectural landscape. 
This change in interest about quality pushed the most of the research carried out in this field, even for those that have taken into consideration the architectural aspect of quality, to reach the quality by identifying the different parametres involved in the "measurement" of this quality, based on evaluation methods and approaches that try to quantify this quality through indicators.

The environmental concerns in the year 2000s prompted the UK government to expand the agenda of Rethinking Construction (Egan, 1998). This extension concerns the design quality indicator (DQI): a tool to measure the quality of the building during the design phase based on the opinions of the various users on the building. This tool was developed by a research group in collaboration with the Construction Industry Council (CIC).

In Europe, precisely in France, Stéphane Hanrot has developed a Building Quality Assessment System called Models for Analysis, Theory and Architectural Experimentation (MATEA) (Hanrot, 2009). It is mainly based on the relativity concept and the comparison of the quality evaluation by viewpoints (opinions) while taking into account their variability in time. The approach relies on tools like Excel and the radar scheme, complementary to the graphic models and numerical features of the architect. These tools facilitate the analysis and the architectural experimentation.

With the evolution of energy interest in construction, the quality of the building is affected with energy concerns. Therefore, researchers suggest integrating these energy concerns into the design process. We can quote Adolph Luc, whose approach consists in integrating knowledge of building energy in the design process using computer tools. This approach is based on the multi-criteria decision support approach in the architectural and urban design process (LUC, 1995).

Currently, the issue of quality in architectural operations is in vogue. However, its evaluation remains as complex and difficult due to the multiplicity of variables taken into consideration. This led the Ramau network (networks of activities and professions in architecture and planning) to carry out research on quality assessment in housing operations sponsored by the Plan Urbanisme Construction Architecture (PUCA France) published in a book entitled La qualité architecturale acteurs etenjeux (Biau and Lautier, 2009). The theme of quality for the Ramau network is treated from different viewpoints. On one hand, quality is the result of the emotions produced by the constructed object. On the other hand, it is more concrete and measurable; the quality concerns energy efficiency, environmental quality, ambience and comfort. This paper focused only in the research of Dehan and Lecourtois. They approached the architectural quality in relation to its two dimensions of art and use, as well as in relation to the architectural object concerned by this quality.

Dehan's research is based on a dual approach. The first proposes a global reflection on the essence of the architectural quality built around the Vitruvian triptych (Solidity, Utility and Beauty) and questions the artistic dimension of production. The second, slightly similar to Hanrot's, consists of the collection of factors involved in quality production. The difference lies in the fine decomposition of the criteria for the evaluation of the intrinsic quality of the architectural object. The objective of this approach is to propose a ranking of the quality-generating factors allowing the construction of a shared argument of judgment (Dehan, 2016).

In this paper, more interest has been focused on the first approach that questions the nature of the object concerned by this quality. Dehan approached the architectural quality by distinguishing the difference between the industrial and the architectural object, whereas most of the quality measurement approaches that are used today are inspired by the manufacturing industry. For Dehan, the 
architectural quality differs from the quality of industrial products by the fact that the architectural overall is more than the sum of the parts. The architectural object is distinguished from the industrial product by two major specificities: it can be assessed as an artwork as it can be evaluated by the multiplicity of its use (Dehan, 2009). As a use, the architectural object is a "unique product" which differs from the industrial product by three points: its functional plurality, its surrounding context and its life span that exceeds several decades or several centuries (Dehan, 2009). As an artwork, the architectural object constitutes a problematic in its qualitative evaluation. "Who can evaluate the artistic value of the architectural object?": The question is complex because it depends on the judgment that differs from one subject to another according to one's identity and acquired knowledge.

While Lecourtois approached the architectural quality through architecturology and its cognitive phenomena: perception and design. She focused on the quality of architectural space rather than architectural quality. According to the phenomenon of perception, the architectural quality of an object becomes a complex division between the value (the intrinsic property) of the same object and the subjectivity of the subject (its identity and sensitivity). Since the properties of an object are invariable and independent of the subject's judgment, the perception of the quality is the result of the personal interpretation of the object properties perceived by the subject according to its senses, subjectivity and identity (Lecourtois, 2009).

While from a conceptual viewpoint, it is admitted by the architectural community that the architectural quality of an object designed by an architect becomes almost automatic since this object is the product of the architect's knowledge. Who knows how to make architecture, would make quality, because architecture cannot exist through mediocrity (Lecourtois, 2009). From a conceptual viewpoint, this quote means that the architectural quality of an object is synonymous of its intrinsic properties, which are the result of the architect's knowledge. Thus, according to the author, and considering architecture as a space designed to be lived and perceived, the perception of an architectural space qualities according to its properties is none other than the re-design of this architectural space according to the senses and the identity of the subject. Moreover, to ensure this quality, it will be necessary to minimise the gap between the two cognitive moments that constitutes architecture according to architecturology; between conceived space and perceived space (between design and perception). Yet, this observation leads to a double problematic: the complexity and the difficulty of constituting this architectural quality by minimising the gap between design and perception ${ }^{2}$ on one hand and assurance of the reality of this perceived quality of the architectural space when its value rests only on a judgment of an observer, ${ }^{3}$ on the other hand.

With this literature review, one can notice that the question of the architectural quality is complex. Besides, in all the studies cited above, they agree that taking into account the user's opinion in the design phase is essential to ensure the quality of the architectural object. This is why it is obvious that knowing how space is perceived by the user allows us to control the architectural quality. If controlling the identity of the inhabitant and his references is impossible, we can at least invest in the mechanism of perception, precisely by focusing on visual sensory information (viewing angles). The visual sense is considered as the most important sense in the mechanism of perception of space; it is the sense of the first discovery that makes it possible to have the first impression. Afterwards, the observer can deepen this sensation with the aid of the other senses. Therefore, consideration must be given to the manner 
of viewing the space by the user in the design process. This allows us to minimise the gap between the space designed by the architect and the space re-designed (seen) by the user.

Among the first architects who approached the importance of the way of space visualisation by the user is Auguste Choisy (1841-1909). He was the first who used the perspective view to explain the composition of the propylaeum of the Acropolis of Athens. Thus, he announced that the principle of the acropolis composition, which has remained a myth for years, is based on the viewpoints of the spectator whose architect chosen beforehand. This is the picturesque principle of architectural composition based on the angle view and the formation of the tables for the spectator. For Choisy, the view's angles are those which the ancients generally seek to maintain. A view angle is more picturesque; a front view is more majestic. Each one has its own role: the view angle is the rule whereas the front view is an exception which is always motivated (Choisy, 1899: 419). For the Greeks, the composition of a complex must belong to a picture that the spectator sees from the first sight. Choisy calls it the principle of the first impression that the Greeks strengthen in their composition.

Constantinos Doxiadis (1914-1975) pushed this hypothesis further and determined the mathematical method with which the buildings of the acropolis were arranged. According to the architect, the viewer was the key of Greek architectural composition. That means, this architectural quality of the Greek building is on the one hand due to the arrangement system of the view angles, which constitutes an architectural course that the spectator will borrow. This approach of viewing angles will be detailed in the analytical part of the manuscript.

In the 1950s and with the housing crisis, Pouillon introduced new ideas and a new vision for the future of the construction of mass housing, which was criticised by most of his colleagues. He called into question what the masters of the modern movement saw as the only way towards modern architecture.

He concretised his ideas thanks to Jacques Chevalier, the newly elected mayor of Algiers at the time, who entrusted him with the construction of more than 7,000 apartments divided into three complexes: Diar Es Saada, Diar El Mahçoul and Climat de France. He wanted to give a new image to the city. For his project, he chose an architect who proved his value with two important projects: the complex of the Old Port of Marseille and the 200 apartments of Aix-en-Provence.

We think that Pouillon's responses to the architectural quality problem concerns a new interpretation of architectural composition that takes into account the viewpoints of the users inspired by the arrangement principle of the acropolis of Athens.

In this article, the aim will be to propose a new perspective on architectural quality. It consists of a new approach in order to obtain an architectural quality in the housing estates through the integration of the users' viewpoints in the architectural composition. It will be through the analysis of the Algerian housing estate "Diar Es Saada" of Pouillon. 


\section{RESEARCH METHOD}

\section{Data Collection}

The entire graphic documents of the case study come either from the national archive of Algiers or from the digital archive of Les Pierres sauvages de Belcastel association. The author has taken care to redraw the necessary parts for the study by tracing them of the original documents. The photos of the case study are taken either directly from the sites by the author or retrieved from different digital archive.

\section{Analysis Method}

The analysis method that we used is based on the fact that the analysis and the design (projet) are two disciplines that intertwine within a dual system that takes us from one to another (Motta and Pizzigoni, 2006). Between the analysis and the design (projet) there is circularity; the ties and relationships which unite them make it impossible to distinguish clearly between these two moments (Motta and Pizzigoni, 2006).

Therefore, the analysis of the case study concerns the Pouillon design process. It tried first to identify the factors generating the architectural form constituted by the human-building-environment interaction. These generating factors are structurally linked together to constitute architectural knowledge. The studies by the Building Performance Research Unit (BPRU) of Markus (1972) and Broadbent (1973) have attempted to rationalise architectural knowledge by subdividing it into separate entities (into families of generating factors) (Mazouz, 2014).

However, this approach of subdivision is opposed to two difficulties. The first concerns the subdivision of architectural knowledge into separate entities, the second concerns the participation of each entity in the design process. To explain the second point, we will use the same example of Mazouz: one of the shape of a building unit, which can be generated by several entities of architectural knowledge that contribute simultaneously to its genesis. The shape of the building unit in question can be generated simultaneously by the environmental aspect and the spatial planning aspect. For Mazouz, the solution to the first difficulty lies in the way to subdivide according to the old concept of Angyal, the structural articulation cited by Broadbent (1988). This concept consists of a subdivision according to the structural articulations of this entity rather than an arbitrary subdivision.

For the second difficulty, the solution lies in the concept of inheritance between the different concepts given by each entity of knowledge. The same subdivision of Mazouz of architectural knowledge has been used in four families which are: the physical environment which concerns the elements related to the environment, the climate, the terrain, the relationships with the surrounding urban areas and the site. The spatial planning concerns the program and the spatial organisation. Sociocultural environment refers to generating ideas, paradigm and principles of composition. The construction system concerns constructive technologies, systems and building processes. This latter factor will not be studied separately but will be integrated into the other three families to show the relationship that exists between design and construction in the architecture of Pouillon. These families will not be present in the text as subsection titles. The transition from one family to another will be as lucid and discreet as possible. This allows avoiding a discontinuity in the 
analysis of the complex. It seems essential to us to show the continuity that exists in the work of Pouillon from the choice of the terrain, the method of implantation, to the spatial organisation of the complex.

\section{CASE STUDY: DIAR ES SAADA}

Diar Saada or "city of happiness" is the first housing complex designed by Pouillon (Figure 1) in the municipality El Madania (Clos-Salembier during French colonisation), a popular district of the city of Algiers: the capital of Algeria, in the year 1953-1954. The complex is located on the heights of Algiers with views of the sea, on sites selected exclusively by Pouillon (Figure 2). The complex of 725 housing units is a part of a low-income housing or Habitation à loyer modéré (HLM): a program to make up for the housing deficit in the capital during the French colonisation, on one hand, and aimed to get rid of the slums in Algiers and on the other hand, to give a new urban image to the capital.

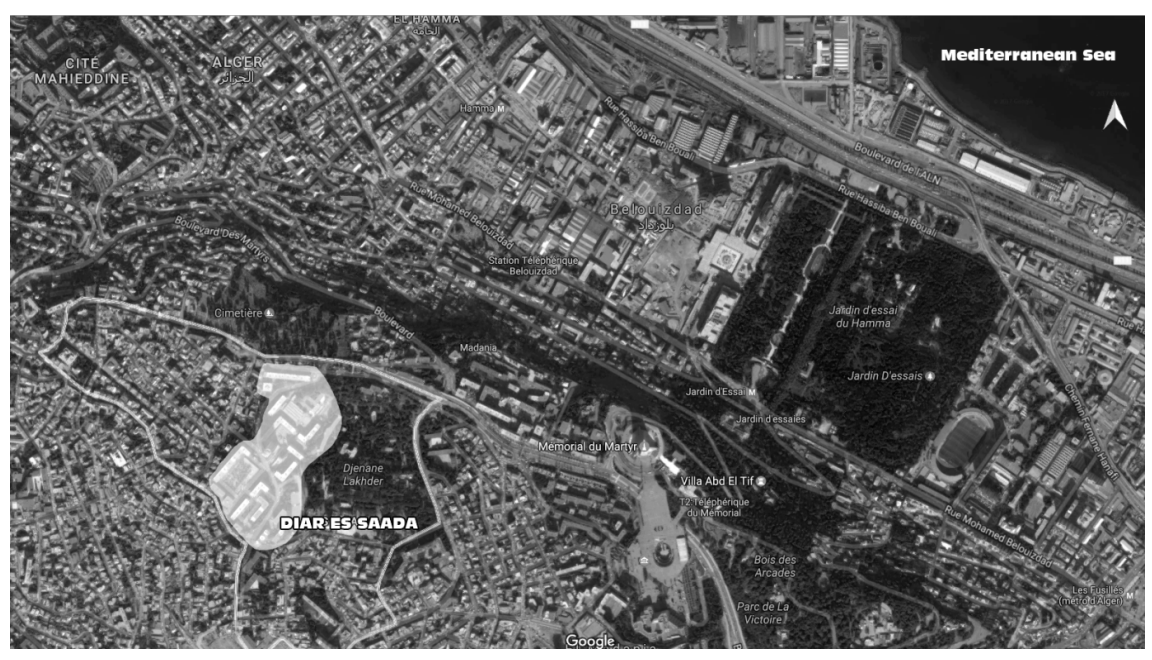

Figure 1. Location of Diar Es Saada

Diar Es Saada complex represents the first of the three Pouillon's complexes built in Algiers, in which he concretised his new vision for the future of the social housing construction. It is also the smallest one, so it is considered as a basic model from which has developed other principles for the construction of the other complexes. Therefore, it allows to better understanding on the viewing angles approach, which is why we chose it as a case study.

The complex occupies a land of more than seven hectares in double slopes that intersect in a basin in the direction of north-east south-west. The largest of the slopes has a vertical drop of 30 metres over a length of 310 metres (Figure 3). This height is covered by users on foot as the main part of the complex is pedestrian. This natural constraint required a spatial configuration that allowed pedestrian to walk the entire complex without worrying about this drop. 


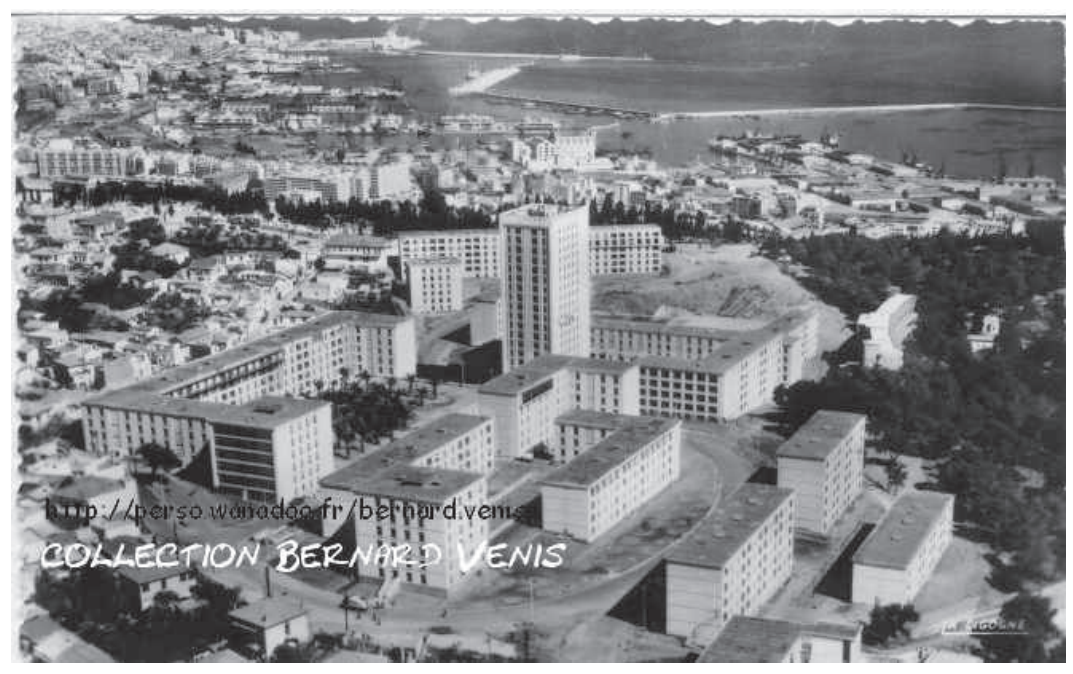

Figure 2. The Complex of Diar Es Saada in the 1950s (Retrieved from http:// diaressaada.alger.free.fr/d-cartespostales/cartespostales.html)
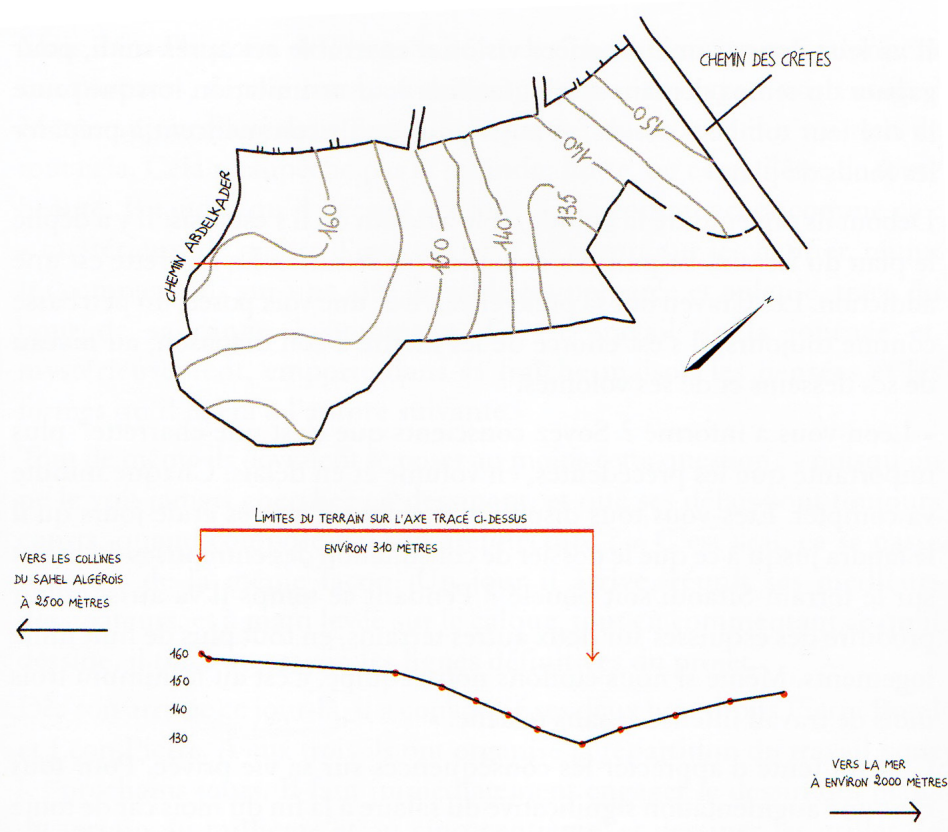

Figure 3. Morphology of Diar Es Saada Land Source: Sayen (2014) 
The complex implantation is along a main axis of perspective. This axis is generated by an angle of $54^{\circ}$ related to the crossroads of the ridge path (chemin des crêtes) (Figure 4). According to Sayen (2014), this angle is a part of a pentagon whose one of its sides is the crossroads of the ridge path, and the other is the axis of perspective. This angle allows the division of the ground into two homogeneous and balanced parts.

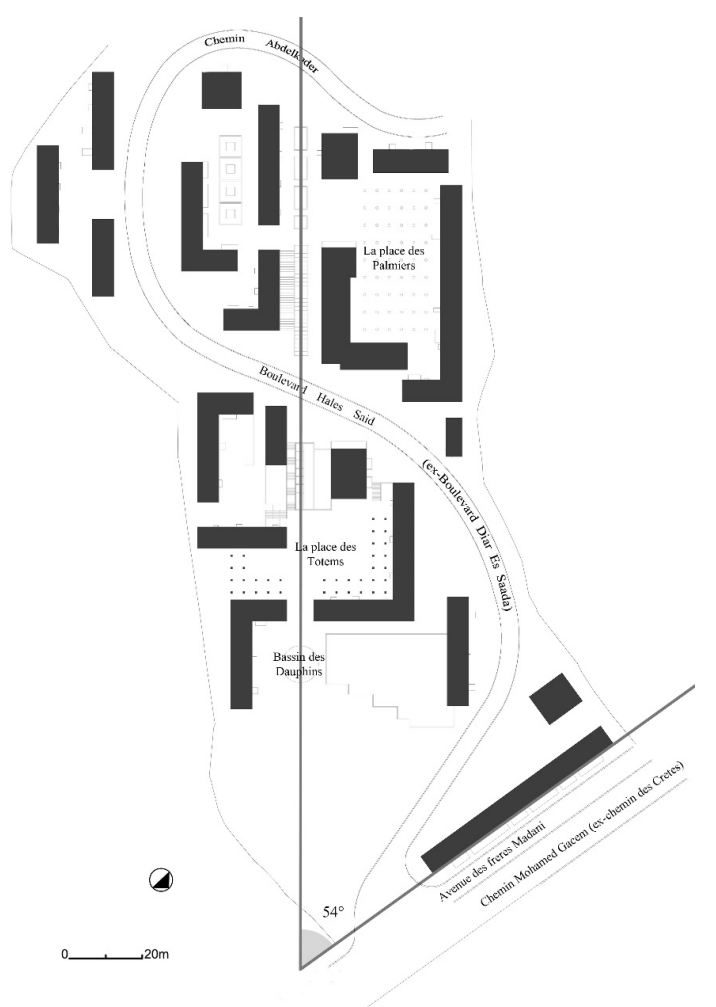

Figure 4. Ground Plan of Diar Es Saada

The development is divided into upper and lower parts by an "S" crossing the entire field following the contour lines. It allows on one side, to solve the problem of mechanical accessibility to the buildings, having regard to the irregular shape of the land. On the other hand, participate in the organisation of the ground plan while being economical in earthwork (Sayen, 2014).

All buildings of the housing estate are either perpendicular or parallel to the axis. With a single dominant orthogonality and different buildings from each other, it produces sequences of spaces varied both by their plan configurations and by the created voids. It is a balance game with non-identical elements constituting a complex that moves away from symmetry, called the picturesque principles of architectural design. It helps to build the overall image of the housing estate seen from the crossroads - we speak about the image seen by pedestrians and not by the aviator - inspired by the Kasbah of Algiers and its acroterions that overlay against 
each other. Pouillon took advantage of the 35 metres vertical drop to stagger the flat roofs of the various buildings of the complex, while keeping a proportion of these offset levels from the crossroads viewpoints. This offset will not allow seeing the facades, to avoid the effect of crushing on less high buildings and catch up on the 35 metres elevation, but only a few walls that emerge and acroterions superimposed (Sayen, 2014).

What is important in Pouillon's approach is that he composed with the built environment. He composed with the city: the perspective axes and visual openings lead one's eye on to the built environment. Moreover, the small passages and squares inside the complex make it a part of the city. According to this vision, urban planning is the result of architecture. This is Pouillon's reaction against the architecture of the ground plan. He explained it very well in Ordonnances, by saying that "when envisaging a city or a part of a city, it is not enough to think only of the plan: one has to be able to imagine the architecture in all its smallest details..." (Pouillon's Ordonnance, as cited in Caruso and Thomas [2014: 53]).

The ground plan much favoured by the modern movement architect who followed the Athens Charter 1933, is based on a horizontal vision of space, an aerial view. According to Pouillon, architecture is viewed by pedestrians and not by aviators. This means that the composition of urban spaces should refer to the height of the human eye, which embraces the architectural object by surrounding it. This is an interpretation of Choisy's lesson on the Acropolis of Athens. He discovered that, to understand the arrangement of the buildings, we must look at the complex through the viewer's eye: everything is arranged in relation to him by following viewing angles. For him, the overall plan of the Acropolis is not an "accumulation of buildings from various periods", but a plan "methodically designed according to a general vision..." (Choisy, 1899: 413).

According to Choisy, the overall plan is made according to symmetry, but not bilateral symmetry. Lucan said it is "visual symmetry, symmetry of the masses, perspective symmetry, picturesque, optical or optical balance, that is, the result of a balancing of the masses (pondération des masses)" (Lucan, 2009: 352) (Figure 5). It is the picturesque principle of an architectural composition.

This paper takes that Pouillon relied on this arrangement principle of the acropolis of Athens to integrate the user's manner of viewing the space in the composition of the housing. This allows reducing the gap between the user viewing (re-design) and the architect design of this space.

To better understand the integration of this user viewing mechanism, reference is made to the work of the Greek architect, Constantinos Doxiadis (1914-1975). He was able in his doctoral thesis, written in German in year 1937, to determine the mathematical method with which has implanted the different buildings of the Acropolis. His hypothesis starts from the same point of view of Choisy, "it is not always easy to remember that these complexes were built by the ancient Greeks not as isolated objects, as we see them today, but as a part of a dynamic urban environment [...]. If we have hitherto failed to recognise that the urban layouts of the archaic, classic, and Hellenistic periods were organised on the basis of a precisely calculated system; it is because we are strongly influenced either consciously or unconsciously by the rectangular system of coordinates (Figure 6) in which every point is established by its positions on a plan in relationship with two lines intersecting at right angles. This system was completely unknown to the ancient Greeks. Their layouts were not designed on a drawing board: each was developed on a site in an existing landscape, which was not subject to the laws of axial coordinates" (Doxiadis, 1972: 4) 


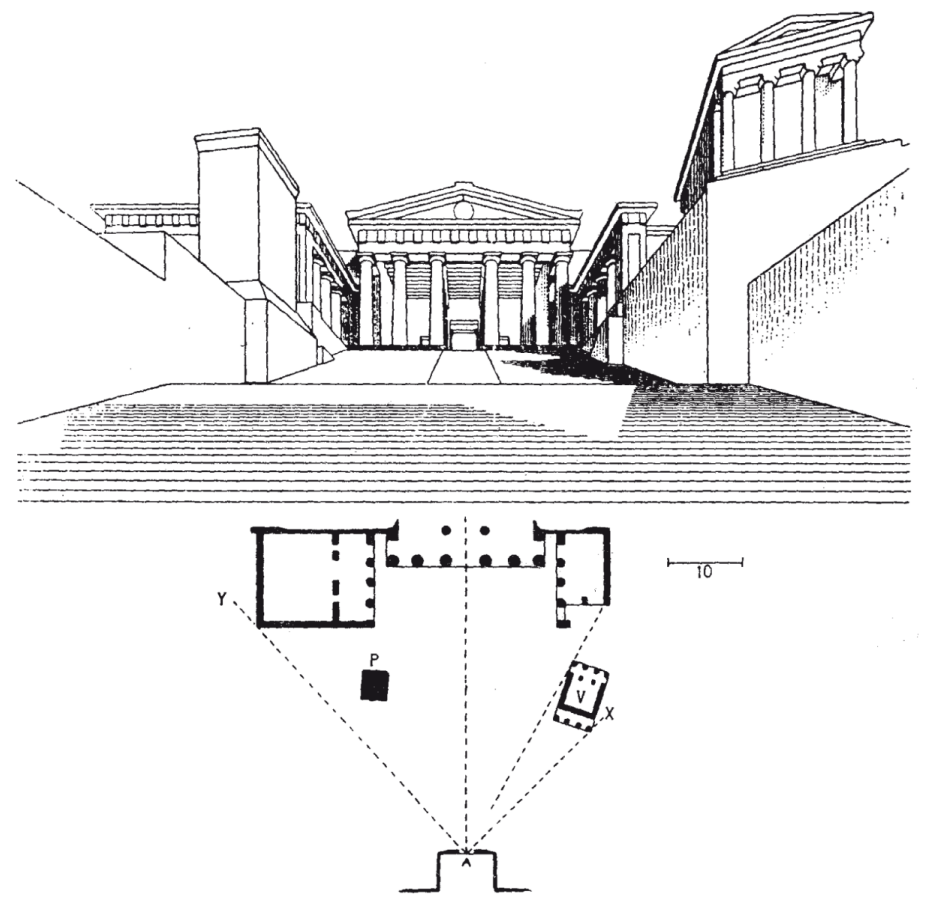

Figure 5. Propylaea of the Acropolis of Athens from Histoire de l'Architecture Source: Choisy (1899: 414)

According to Doxiadis' hypothesis, pedestrian was the central point in the Greek positioning system, using the polar coordinate system. Each object was determined by the position of the pedestrian (Figure 7). This allows determining accurately the position of each building of the Acropolis with regard to a selected viewpoint which is part of the promenade designed by the architect. Usually the main viewpoint, according to which the buildings are located, is the entrance highlighted by the Propylaea.

Composition rules of acropolis established by Doxiadis (Figure 8) are basically two principles: the first is that all the buildings are positioned relatively to the viewpoint by viewing angles that are either part of a system of twelve parts (360/12 $=30^{\circ}$ ) or a system of ten parts $\left(360 / 10=36^{\circ}\right)$. The second principle is that in addition to the viewing angle, the position of a building is also determined with respect to its distance from the viewpoint which is calculated by foot, which was usually a sequence of 100 feet (100-200-300-400-500 in the case of the Acropolis). He also noticed that the usually central angle of the composition was left free of buildings and opened directly to the surrounding countryside. It represents the way that the viewer has to borrow: it is the "sacred way" (Doxiadis, 1972: 5). 


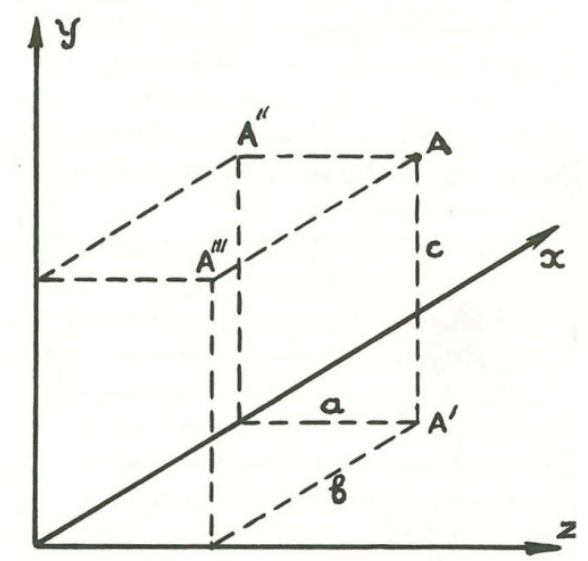

Figure 6. Cartesian Coordinates System Source: Doxiadis (1972)

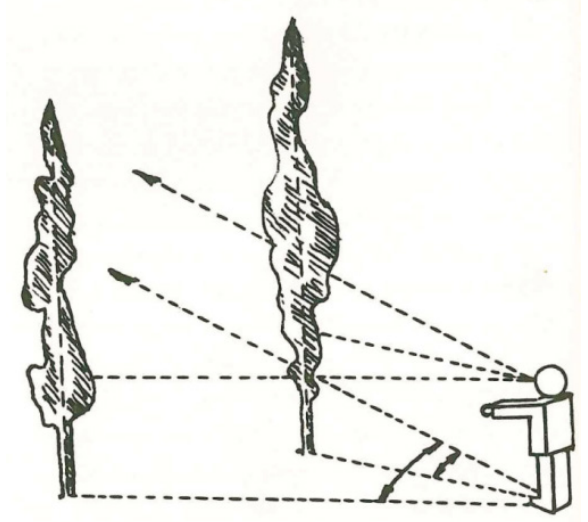

Figure 7. Polar Coordinates System Source: Doxiadis (1972) 


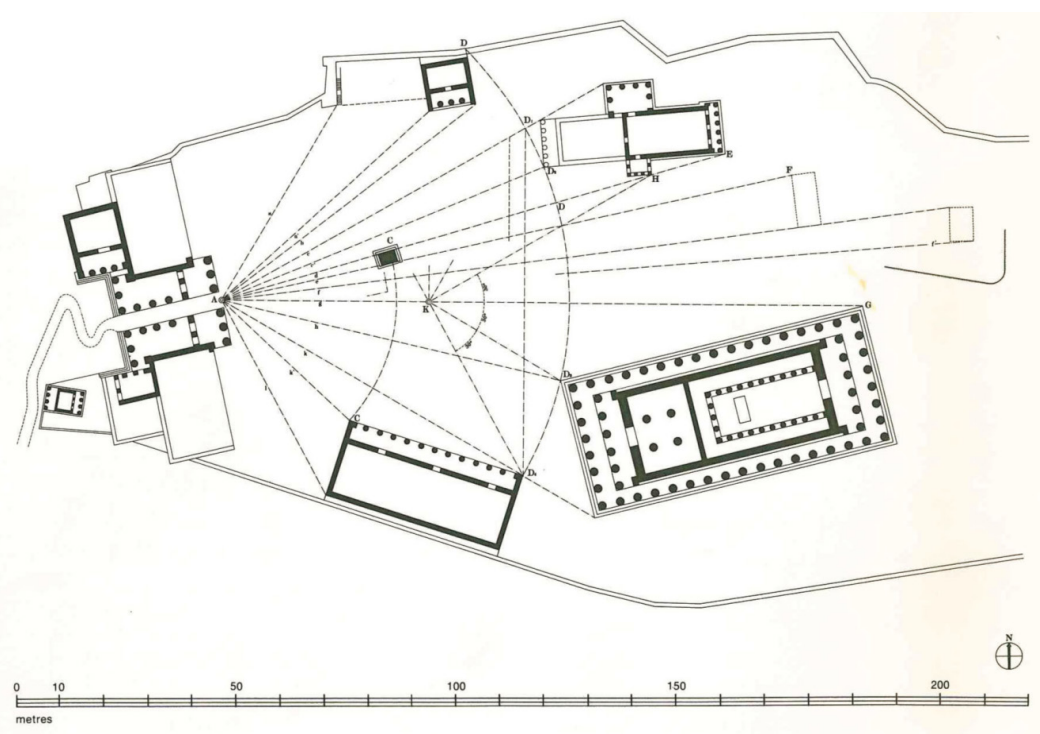

Figure 8. Athens, Acropolis III, after 450 BC Plan, from "Positioning Logic of the Acropolis of Athens Buildings" in Architectural Space in Ancient Greece Source: Doxiadis (1972: 37)

The analysis of Diar Es Saada is pushed one-step further about the presence of viewing angles in the composition of the complex. This analysis allows perceiving this sequence of landscape views inside the complex (Figure 9). One can notice the use of three types of angles: $22.5^{\circ}, 30^{\circ}$ and $36^{\circ}$, whose centre is part of a perspective axis (Figure 10) which cuts the development into two balanced entities. In this perspective axis, which is the main route used by pedestrians, it has been possible to determine four viewpoints which determine the position of the buildings that animate this route.

The viewpoints determined in this study are not the only ones that exist. This paper focused only on the main viewpoints, which on the one hand, are part of the main course drawn by the architect, and on the other hand, they constitute transaction points that allow moving from one landscape to another. These are the points that materialise the first impression (Points A and B: constitute the beginning of the composition; Points $C$ and $D$ : constitute the last step of the stairs that reveals another scene).

It should be noted that there are some inaccuracies in the angles which have been identified. This can be explained by the fact that the system of polar coordinates was not the only system used to arrange the buildings. There were also the orthogonal grid, the module of the "marmite", 4 and the bay (Tehami, 2017).

The first viewpoint, called "A", is the same point from which the whole composition begins. It is the first contact, the first impression the pedestrian can get of the complex.

The angle ae $=e i=180 / 5=36^{\circ}$ (Figure 11 ) divides the whole into two equal parts, in which the viewer can feel the visual symmetry in relationship to the axis $(A e)$. This angle cannot be seen now because of the density of the vegetation 
and a fence wall added around the ridge, which block the view from this point A. However, the picture of the Figure 1 1, taken in the $50 \mathrm{~s}$, even if it does not correspond exactly to the position of point $A$, it confirms the presence of this viewing angle.

The angles $a c=b e=d g=f i=180 / 8=22.5^{\circ}$ (Figure 10), allow one to perceive the visual balance provided by the constant rhythm of the angle 180/8, according to which the buildings are placed, from viewpoint $A$.

The second point of view, called "B", is the entrance to the interior of the complex. And the third point, named " $C$ ", coincides with the last step of the first central staircase, also offers this impression of visual balance which can be appreciated by the human eye.

In point $B$ the angles are: $a c=b d=c f=e g=f h=180 / 8=22.5^{\circ}$ (Figure 12)

In point $C$ the angles are: $a c=b d=c e=180 / 5=36^{\circ}$ (Figure 13)

The same sensations of visual balance can be found in the fourth viewpoint, named "D", which coincides with the last step of the second central staircase with angles $c e=d f=g h=180 / 6=30^{\circ}$ and $a c=b d=180 / 8=22.5^{\circ}$ (Figure 14). Moreover, there is the visual symmetry of angles $a e=f h=49^{\circ}$ in relationship to the angle (ef).

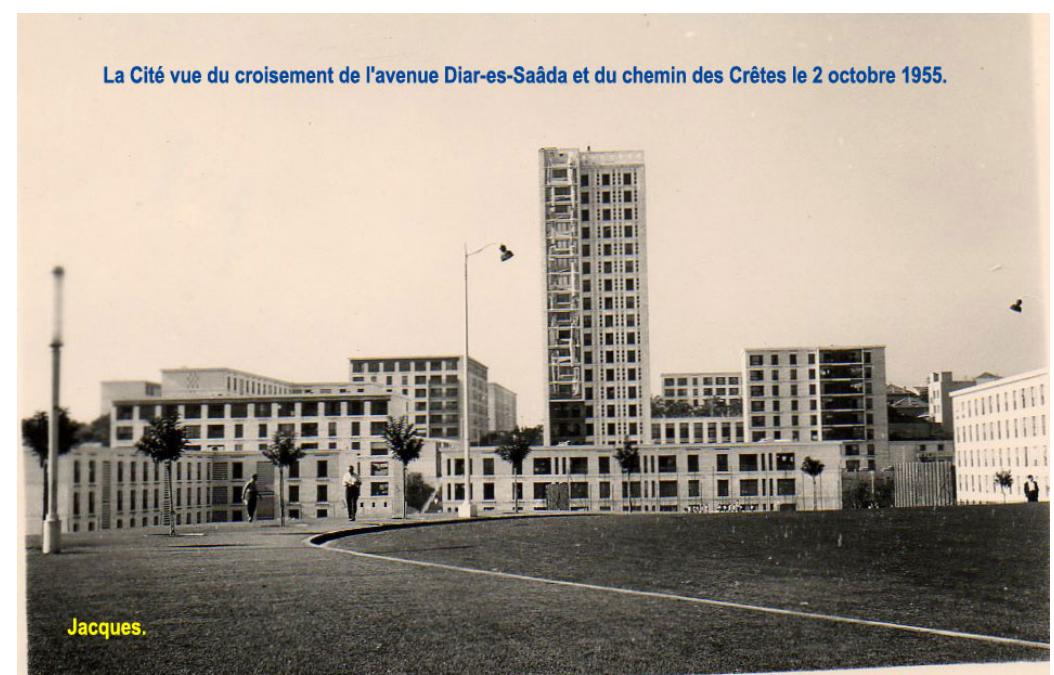

Figure 9. Diar Es Saada, View from the Square of Palm Trees (Retrieved from http:// diaressaada.alger.free.fr/d-cartespostales/cartespostales.html) 


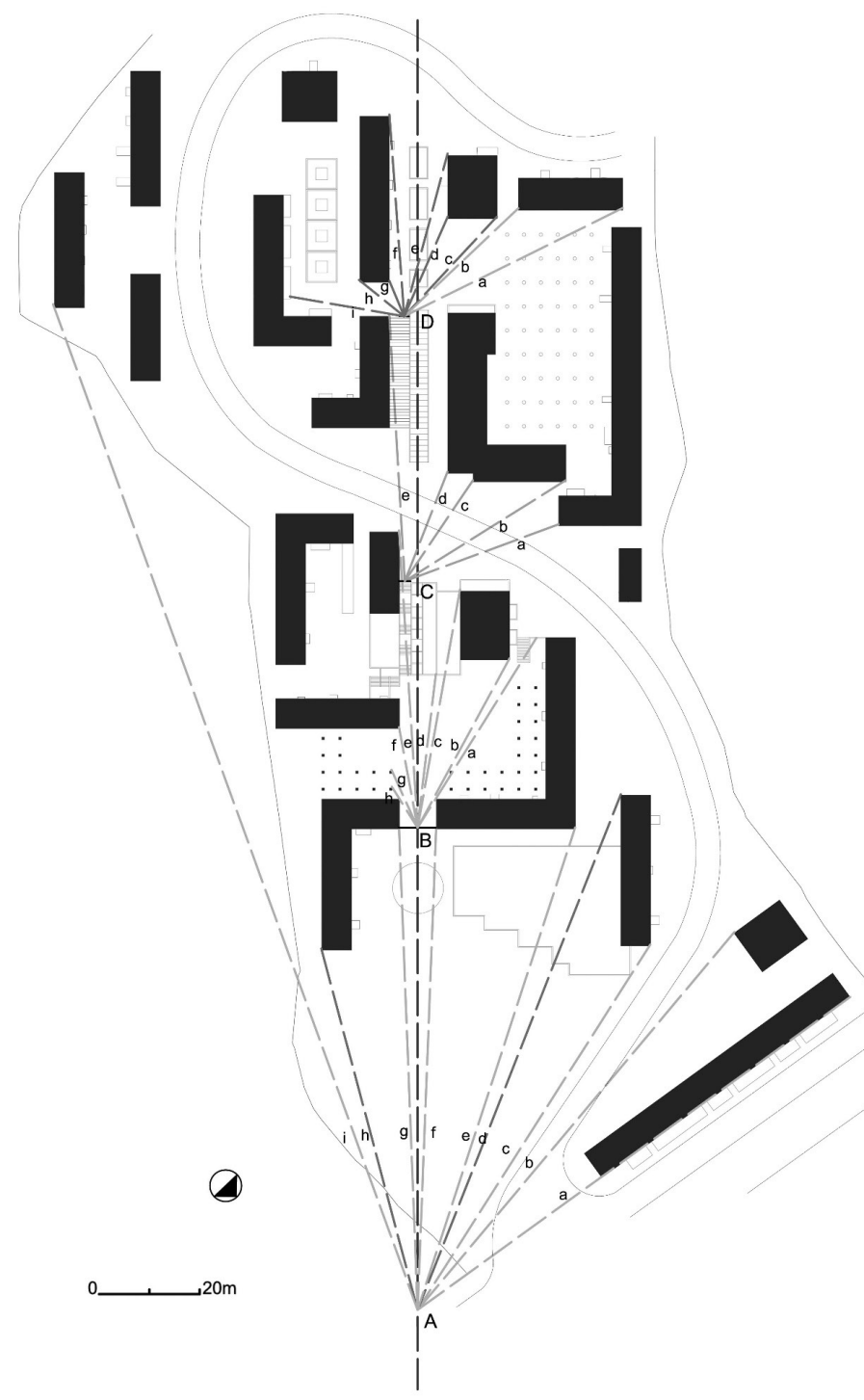

Figure 10. Diar Es Saada with Visual Symmetry along the Main Axis of Perspective 

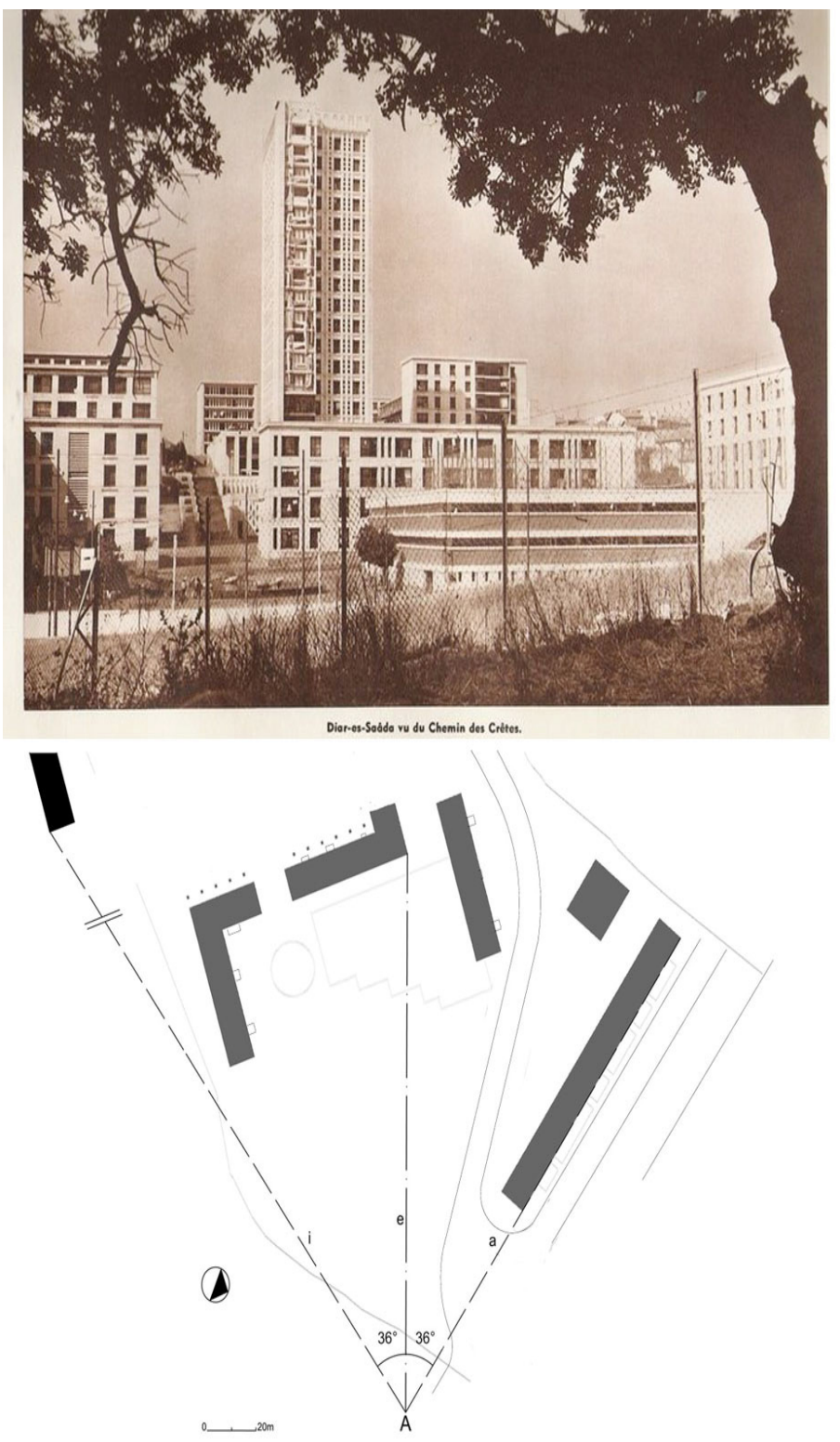

Figure 11. Visual Symmetry $\left(36^{\circ}\right)$ from Viewpoint $A$ 

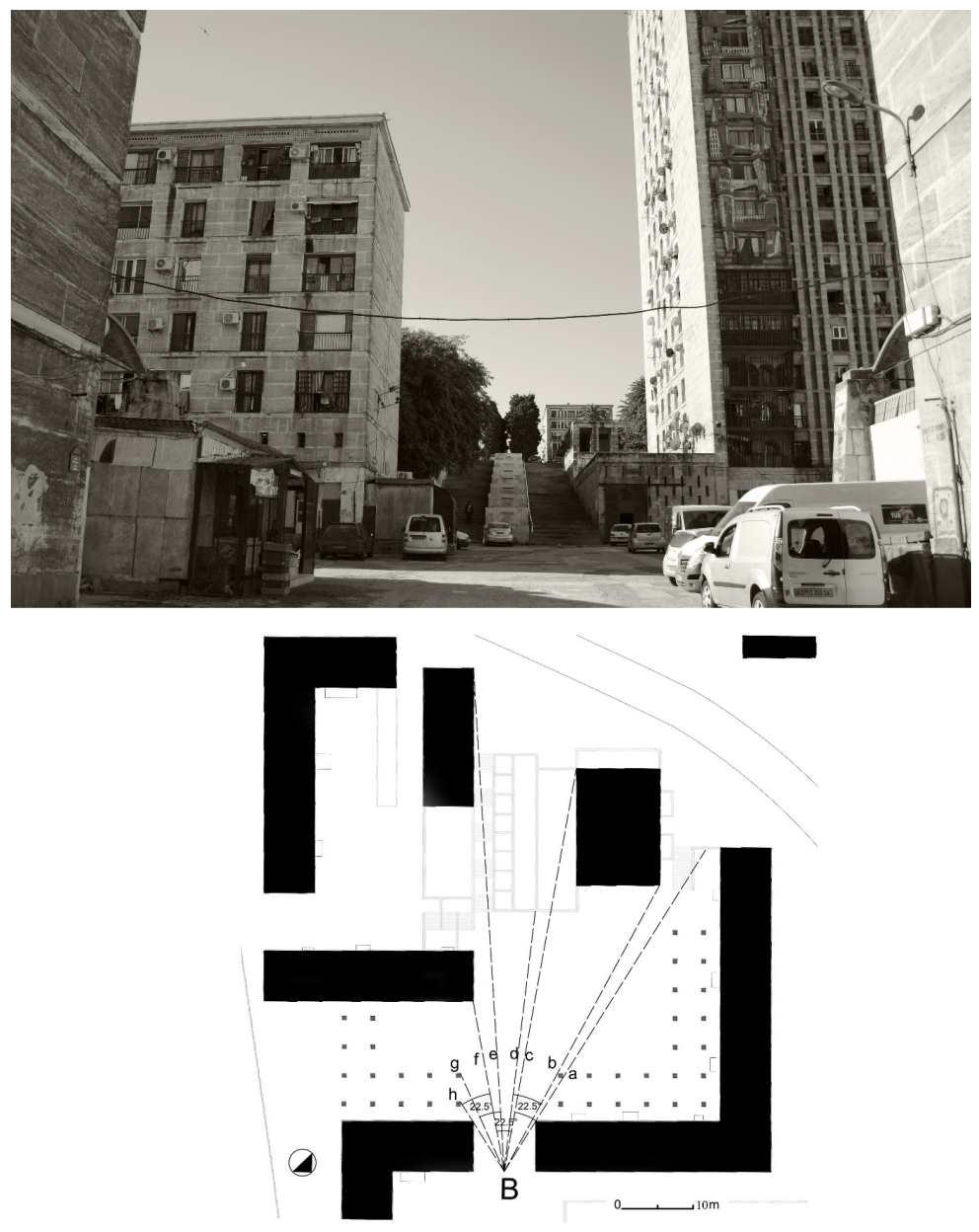

Figure 12. Visual Balance $\left(22.5^{\circ}\right)$ from Viewpoint B 

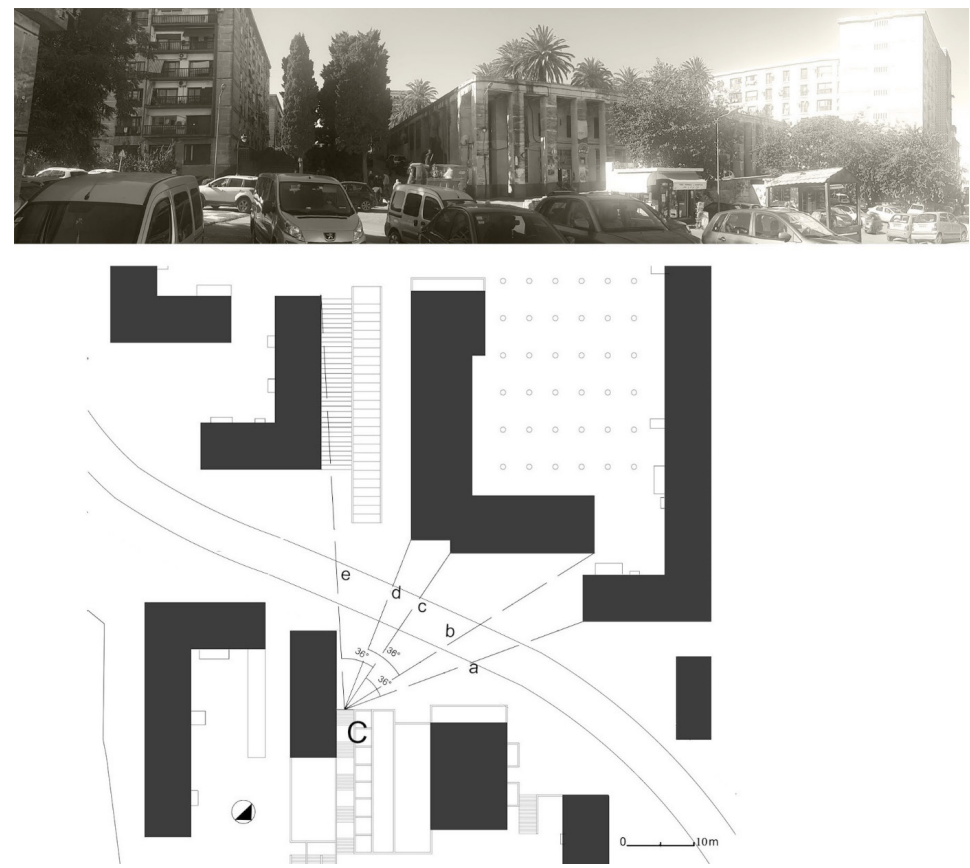

Figure 13. Visual Balance $\left(36^{\circ}\right)$ from Viewpoint C
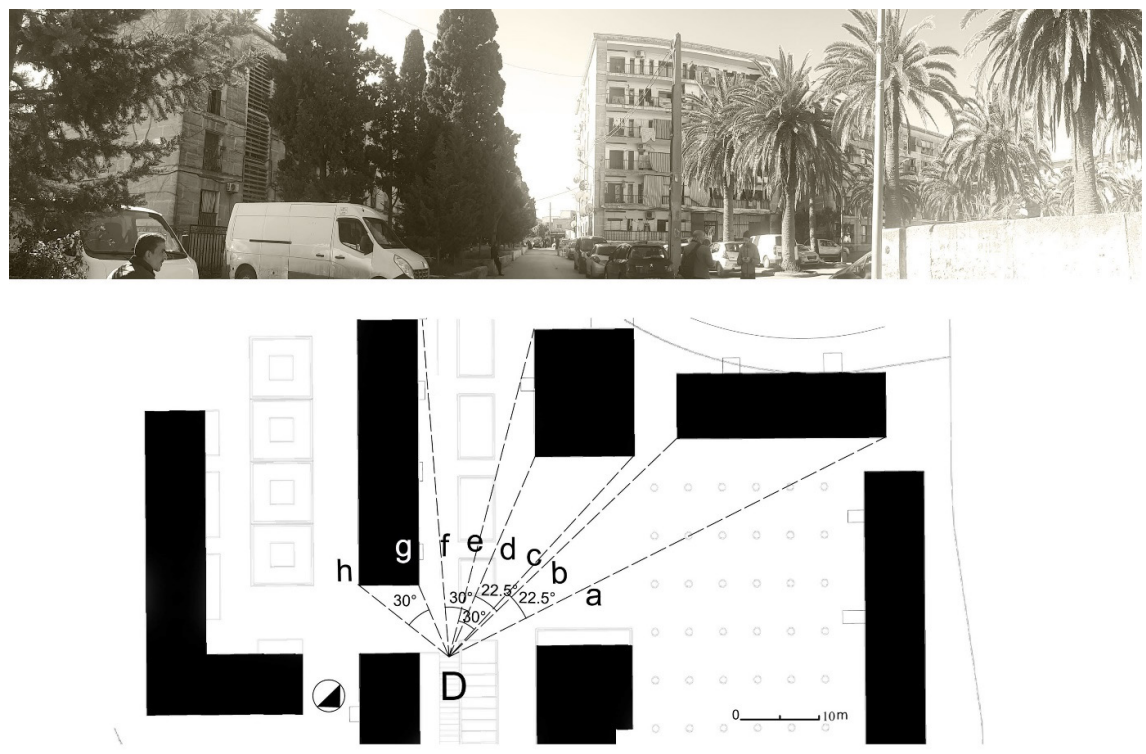

Figure 14. Visual Balance $\left(30^{\circ}\right.$ and $\left.22.5^{\circ}\right)$ from Viewpoint $D$ 
The same route can be taken in the opposite direction from viewpoint $D$ to viewpoint $A$ while keeping the same impressions with a few differences in the angles.

It should be noted that for the moment, this paper cannot confirm exactly that Pouillon applied this approach of viewing angles as shown previously (as Doxiadis's hypothesis for the acropolis of Athens). Unfortunately, Pouillon did not leave detailed documents on his architectural composition. However, this study can confirm the existence of the visual symmetry and mass balance according to precise viewpoints in the composition of the complex of Diar Es Saada.

Hence, it is a new interpretation of the architectural composition that ensures the architectural quality of the housing complex. It is through a system that reduces the gap between the object designed by the architect and the object seen by the user. This new interpretation is the result of the combination between two composition principles: the principle of traditional symmetry and the picturesque (perspective symmetry). The principle of symmetry is represented by the orthogonal grid and the Cartesian coordinate system. While the principle of the picturesque or the perspective symmetry is represented by the architectural promenade and the polar coordinates system.

The analysis of the complex Diar Es Saada allowed noting the presence of a combination between the polar coordinates and the Cartesian coordinates system in the composition of the complex. The Cartesian coordinates system allowed arranging the buildings according to a modular orthogonal grid. It regulated the composition of the complex and created enclosed spaces that are not entirely shut in. This generated open angles as well as passages between buildings made the space closed and fluid at the same time. Nevertheless, the polar coordinates system allowed arranging the buildings according to the viewpoints, which were a part of a planned route borrowed by the users.

The importance of using viewing angles in the architectural composition of housing lies in the fact that architecture is always viewed by the human eye. Consequently, the use of this approach allows the integration of the building into its immediate environment, and generating landscape tables that change according to the different viewpoints of the user. Furthermore, it is the principle of composition of most great buildings throughout the history of architecture. At the time, they completely ignored the Cartesian coordinate system, and relied on the polar coordinate system to arrange their buildings.

While the consequences of the non-use of this approach is that the building will be designed as a single object from its context, and its composition is done following an aerial view in two dimensions (ground plan). Thus, the user is not considered in the organisation of spaces, and the external landscape is the result of voids resulting from the Cartesian arrangement of the different buildings.

Subsequently, the relationship between viewing angles and architectural quality becomes evident. This quality of housing, which is considered as architectural object in an architectural space, is perceived and appreciated by the user following a perception mechanism, whose visual sense is the important element in this mechanism. As a result, ensuring the visualisation of the architectural space to the user (re-design), as designed by the architect (landscape tables that scrolls while moving), is to ensure the real architectural quality of different spaces generated by the architect.

Besides, in the other categories of housing where the quantity is less solicited, the quality can be obtained by the use of noble materials, street furniture, and luxury accessories which force the impression of quality even in the presence of an 
architectural mediocrity. While in low-income housing, the quantitative character exceeds the qualitative one because of a limited budget. And knowing that quality initiatives are often expensive and not a luxury that social housing can afford, this free approach is an important factor of architectural quality. It allows investing in the exploitation of the qualities of the architectural space instead of camouflage accessories.

\section{DISCUSSION}

According to the literature review presented previously, the question of the architectural quality can be approached from different viewpoints. Studies have approached it by measuring the quality through indicators that constitutes a toolbox for the designer. While other studies focused on the integration of technical knowledge in the design phase through multi-criteria decision support methods. Further studies prefer to identify the nature of the object concerned by this quality through the architecturological viewpoint.

Approaches based on indicators of quality as design quality indicator (DQI) (Gann, Salter and Whyte, 2003). The Post-Occupancy Review of Buildings and their Engineering (PROBE) (Bordass et al., 1999), Housing Quality Indicator (HQI) (Department for Transport, Local Government and the Regions [DTLR], 2000), Building Research Establishment Environmental Assessment Method (BREEAM) (Crawley and Aho, 1999) and MATEA (Hanrot, 2009) are in fact a toolbox that allows the architect to see the discrepancy between the different opinions of the producers and users of the building.

Maybe they are sufficient for an industrial object or for certain types of buildings with an industrial character superior to the architectural one (factories or services buildings). However, they are incomplete for the housing in which the architectural character is stronger (the housing is an architectural object more than an industrial one) because the architectural overall is more than the sum of the parts. These indicator approaches ensure the quality of the building parts. They can be a pure technical aspect (construction quality) which includes all the basic requirements such as waterproofing, durability of materials, ventilation, acoustic and thermal insulation: it can be of a socio-cultural aspect that concerns the standard of living, the social and cultural demands. However, these indicators will never allow the architect to ensure the architectural overall of the housing complex. It is because ensuring the quality of the building parts does not automatically ensure a total quality of the building (of the complex in the case of a housing estate).

In fact, the approaches that quantify and make measurable the architectural quality are a part of the modern movement vision. This industrialisation vision of housing following the example of the manufacturing industry has made the crisis of architecture. The architect is no longer able to control the total quality of the building, from the design phase to the realisation. The engineer, in most cases, is responsible for the quality of the various constructive elements of the building, whereas the architect becomes only responsible for the design part (le projet).

This invention of "the design" or le projet allows architecture to gain autonomy from the construction (realisation phase). Henceforth, architectural concepts such as proportion and style, which their justifications were directly in construction, are reasonable in the geometric lines, and drawing away from the site. The Cartesian 
coordinate system in two dimensions (aerial view) is mostly used. Moreover, the engineer handles the translation of this drawings or the design in a real construction.

The viewing angles approach can be a complementary solution to the indicators approach in order to ensure the quality of the architectural overall of the housing. The approach is based on the two principles of composition: symmetry and picturesque. The user's manner of viewing the space (pedestrian) is the key of this approach. Everything is positioned in relationship to the user unlike the composition based on the ground plan and the aerial view.

If the architects of the modern movement, like Le Corbusier and Mies van der Rohe, opted for the ground plan and the aerial view for the composition of the housing, they would provide more movement and dynamism to the ground floor. They did it by freeing the interior plan from the regularity and limitations of the loadbearing wall, and by choosing new construction systems which free walls from their structural function (Lucan, 2009). Thus, the wall becomes an element which shapes space and participates in its articulation. Slightly, they reinterpreted the asymmetry and picturesque of the Greeks by using it in the free design of the floor plans.

While on the contrary Pouillon provided this dynamism on the outside by creating an interior landscape of the housing estate. "This is, undoubtedly, one of the major qualities of Pouillon architecture; the ability to articulate spatial sequences in a game of pieces of varied scales" (Petruccioli, 2001). This can be confirmed by comparing the ground plane of Diar Es Saada (Figure 15) and the plan of Mies van der Rohe's brick country house (Figure 16). That, which Mies did to compose the ground plan of a dwelling, was done by Pouillon in the composition of an entire housing complex. That means Mies' idea of open corners so as to give dynamism to the ground floor can be found in Pouillon's designs for the exterior space of his housing complexes.

It is as if Pouillon saw the entire housing estate as a house in which the walls never intersect, like in Mies' country house, are the buildings of the complex. In addition to that, the rooms created by the walls of the brick country house are the squares of the housing estate. This is a new Pouillon's interpretation of architectural composition that allowed finding a traditional composition in the same building, based on symmetry and a regular orthogonal grid, the principles of picturesque composition, based on visual balance and the balancing of the masses. This is what confirms the timeliness of Pouillon's solutions: he considered the inhabitant as the central point in housing estate design while studies have proposed to do so only recently. 


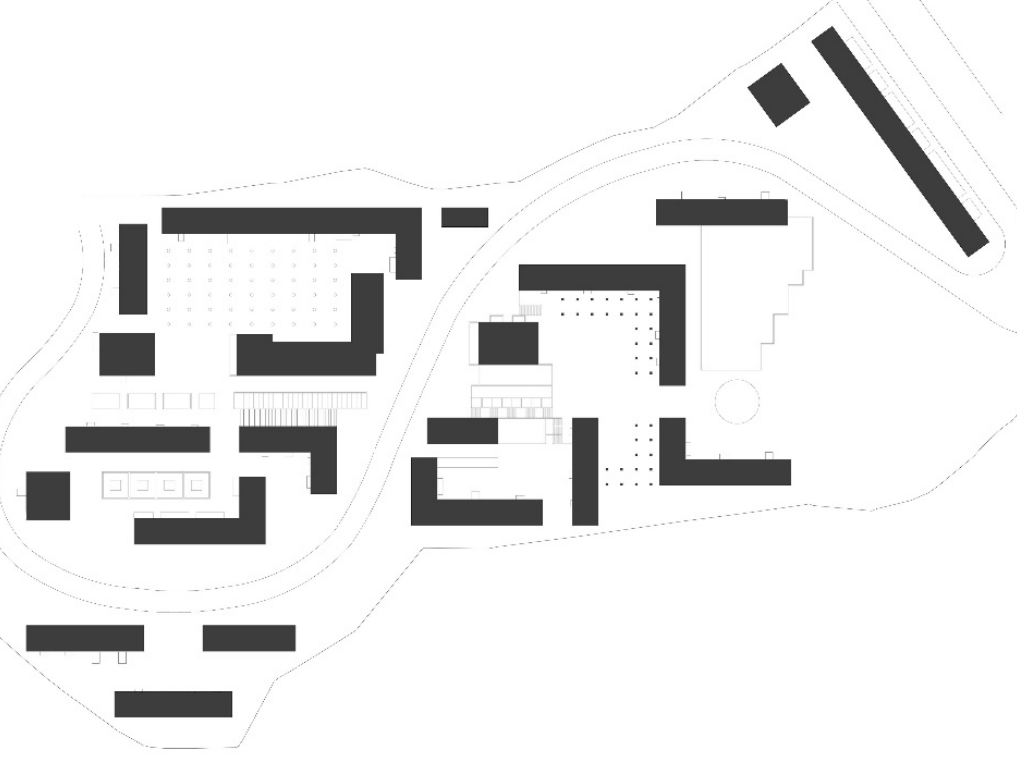

Figure 15. Diar Es Saada of Pouillon

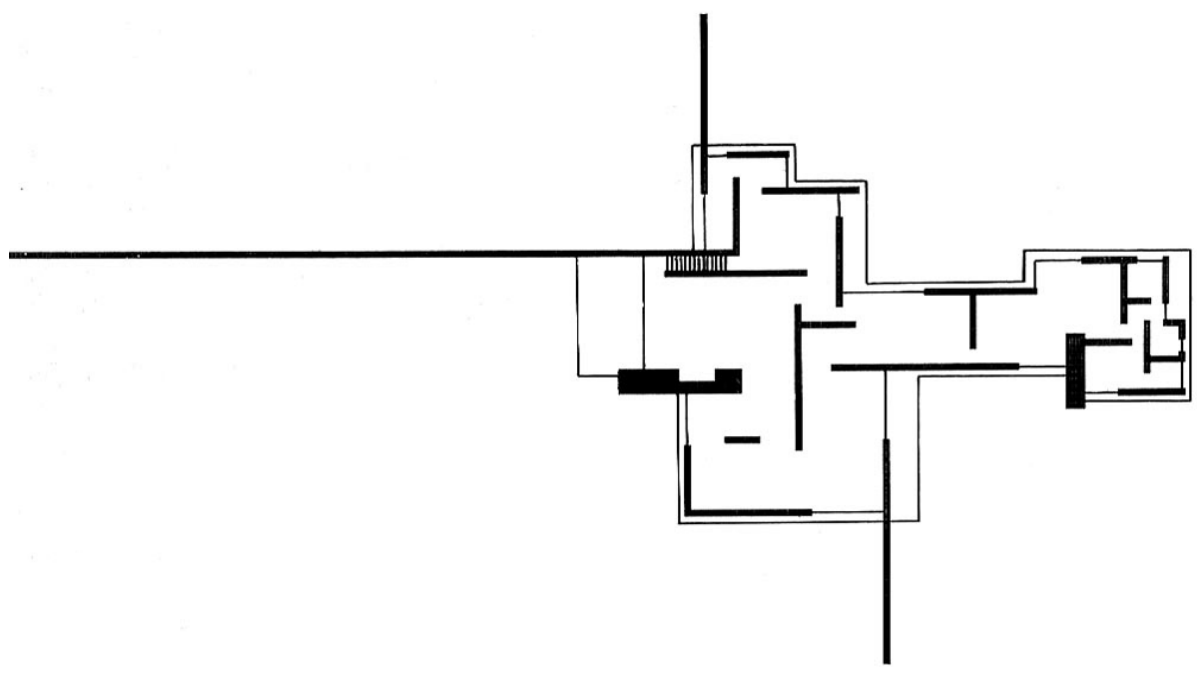

Figure 16. The Brick Country House of Mies van der Rohe 


\section{CONCLUSION}

The case study of "Diar Es Saada" presents an example of a housing estate whose pedestrians are taken into consideration in the design of the complex. The user becomes the main actor in the development of the complex. Everything is built around him. It was made possible by Pouillon's new interpretation of the architectural composition by reconciling the two principles of symmetry and picturesque in the same composition. He managed to minimise the gap between the designed and re-designed (seen) object. The viewing angles' approach can be identified in the arrangement of Diar Es Saada buildings. It constitutes the architectural promenade inspired by the Acropolis of Athens.

This viewing angles' approach allowed the user to visualise the architectural space as conceived by the architect, which amounts to ensuring the real architectural quality of the different spaces. Besides, in low-income housing, quality initiatives are often expensive, which makes this free and long term approach an important factor of architectural quality that allows to invest in exploiting the qualities of the architectural space, instead in the accessories that generate an artificial architectural quality in short term, and that usually exceed the initial budget. The application of this approach allows a unique final result: the landscape generated depends on the context as well as the architectural knowledge of the architect.

The paper suffers several limitations: one of them is that it remains to confirm the real application by Pouillon of the viewing angles' approach in the composition of Diar Es Saada. This study shows only the presence of viewing angles in the arrangement of the buildings of the complex. Thus, it would be interesting in future researches to try to find the method with which the viewing angles are applied in the architectural composition of Pouillon and if it corresponds to the Greeks' acropolis of Athens.

From the users' point of view, another concern is this study focused only on the viewing angles seen by the architect. It would be very interesting to see if the users share this same point of view and if this approach really improves the architectural quality of housing just like the architect expects.

\section{ACKNOWLEDGEMENTS}

This article is part of a doctoral research conducted by the author in both Universite des Sciences et de la Technologie d'Oran Mohamed Boudiaf, USTO-MB in Algeria and Politecnico di Milano in Italy (exchange studies). The research topic is the relationship of continuity between design and construction in social housing design process and its impact on architectural quality in Algeria.

This work was supported by Université des Sciences et de la Technologie d'Oran Mohamed Boudiaf, USTO-MB.

It is necessary to point out that this research was a little hard to do due to the scarcity of graphic documents. This is one of the reasons why the work of Pouillon is greatly unknown. This lack of raw material makes the work of researchers difficult and prevents them from doing in-depth studies.

In our case, the analysis of Pouillon's housing estates was possible thanks to the archives of the Les Pierres sauvages de Belcastel association. Despite the small amount of material, it was possible to carry out a minimum of research work. 


\section{NOTES}

1. The Directorate of Habitat Programs and Property Promotion in Algeria establishes technical and functional requirements applicable for social housing (Ministere de l'Habitat et de l'Urbanisme, 2007).

2. The perception of a space differs from one subject to another according to their senses and identities.

3. Lecourtois calls this an architectural quality of social representation according to which the subject gives the perceived space a representative image of an idea derived from social values.

4. A marmite is a hollow square, part of the floor structure invented by Pouillon made of staff (a mixture of plaster and fibre) or cement, through which a steel frame and concrete pass, like ribs, to support the floor.

\section{REFERENCES}

Barazzetta, G. (2016). Composition, structure and materials: Simultaneity without concession. In C. Sayen and J.L. Bonillo (eds.). Entretien Fernand Pouillon, 30th Anniversary of His Death 1986-2016: The Legacy of Fernand Povillon, the Architect in the Society. Toulouse, France: Pierre Sauvage de Belcastel. . (2001). I'Exigence de la construction. In J.L. Bonillo (ed.). Fernand Pouillon Architecte Méditerranéen. Marseille, France: Imbernon.

Biau, V. and Lautier, F. (2009). Processus d'Engendrement de la Qualité et Négociations Entre Acteurs de l'Architecture. Paris: Ramau.

Bordass, W., Cohen, R., Standeven, M. and Adrian, L. (1999).LPROBE:Post-Occupancy Review of Buildings and their Engineering: 2. Technical Performance of the Buildings Surveyed, with Some Implications. North Yorkshire, UK: The Usable Buildings Trust. Available at: http://www.usablebuildings.co.uk/Probe/ ProbePDFs/BRI2.pdf.

Broadbent, G. (1988). Design in Architecture: Architecture and the Human Sciences. London: David Fulton Publishers.

—. (1973). Design in Architecture: Architecture and the Human Sciences. London: John Wiley and Sons.

Building Performance Research Unit (1972). Building Performance. Great Yarmouth, UK: Applied Science Publishers.

Caruso, A. and Thomas, H. (2014). The Stones of Fernand Pouillon, An Alternative Modernism in French Architecture. Zurich: gta Verlag.

Choisy, A. (1899). Histoire de l'Architecture. Paris: Gauthier-Villars.

Conrad, C. (2009). Qualité vs quantité dans la production actuelle du logement social. In V. Biau and F. Lautier (eds.). Qualité Architecturale Acteur et Enjeux. Paris: Ramau, 71-87.

Crawley, D. and Aho, I. (1999). Building environmental assessment methods: Applications and development trends. Building Research and Information, 27(4-5): 300-308. https://doi.org/10.1080/096132199369417.

Deeb, S. (2008). Contribution méthodologique à la maîtrise conjointe de la qualité d'un produit et de ses processus de production par une modélisation des concepts qualité. PhD diss. Université de Nancy. 
Dehan, P. (2016). Pertinence d'une approche globale de la qualité architecturale dans l'optique de la construction d'un jugement critique raisonné. PhD diss. Université Paris-Est.

— - (2009). La qualité architecturale entre art et usage. In V. Biau and F. Lautier (eds.). Qualité Architecturale Acteur et Enjeux. Paris: Ramau, 88-94.

Department for Transport, Local Government and the Regions (DTLR) (2000). Housing Quality Indicators. London: DTLR.

Doxiadis, C.A. (1972). Architectural Space in Ancient Greece. London: MIT Press.

Durand, J.N.L. (1840). Précis des Leçons d'Architecture. Vol. 1. Paris: Chez l'Auteur.

Egan, J. (1998). Rethinking Construction. London: The Construction Task Force.

Froman, B. (1998). Le Manuel Qualité: Outil Stratégique d'une Démarche Qualité. 2nd Ed. Saint-Denis, France: Association Française de Normalisation (AFNOR).

Gann, D.M., Salter, A.J. and Whyte, K. (2003). Design quality indicators as a tool for thinking. Building Research and Information, 31 (5): 318-333. https://doi.org/1 $0.1080 / 0961321032000107564$.

Hanrot, S. (2009). Evaluation relative de la qualité architecturale: Une approche par le point de vue des acteurs. In V. Biau and F. Lautier (eds.). Processus d'Engendrement de la Qualité et Négociations Entre Acteurs de l'Architecture. Paris: Ramau, $111-126$.

Le Corbusier, J.P. (1984). OEuvre Complete 1929-1934. Zurich: Editions d'Architecture.

Lecourtois, C. (2009). Quelles qualités pour l'espace architectural. In V. Biau and F. Lautier (eds.). Processus d'Engendrement de la Qualité et Négociations Entre Acteurs de l'Architecture. Paris: Ramau, 71-87.

Luc, A. (1995). I'Intégration des connaissances techniques dans le processus de conception architecturale et urbaine. HDR diss. Université Paul Sabatier.

Lucan, J. (2009). Composition, Non-Composition: Architecture et Théories, XIX-XXe Siècles. Lausanne: Presses Polytechniques et Universitaires Romandes (PPUR). . (2003). Fernand Pouillon: Architecte. Paris: Arsenal.

Mazouz, S. (2014). Éléments de Conception Architecturale. Ben Aknoun, Algeria: Office des Publications Universitaires.

Ministère de l'Habitat et de l'Urbanisme et de la Ville (2007). Prescriptions Techniques et Fonctionnelles Applicables Aux Logements Sociaux, Algeria. Algers, Algeria: Ministère de l'Habitat et de l'Urbanisme et de la Ville. Available at: http://www.mhuv.gov.dz/Fichiers/Divers/Prescriptions\%20techniques\%20 et\%20fonctionnelles\%20applicables\%20au\%20logements\%20sociaux.pdf.

Motta, G. and Pizzigoni, A. (2006). Les machines du Projet: I'Horloge de Vitruve et Autres Écrits. Paris: Anthropos-Economica.

Petruccioli, A. (2001). Les choix typologiques de Fernand Pouillon. In J.L. Bonillo (ed.). Fernand Pouillon Architecte Méditerranéen. Marseille, France: Imbernon.

Pouillon, F. (1968). Mémoires d'un Architecte. Paris: Seuil.

- (1953). Ordonnance. Hôtels et Résidences des XVI, XVII et XVIII Siècles, Ordonnances des Cours et des Places, Ensembles Harmonieux d'Aix en Provence, Relevés et Dessinés par l'Atelier de Fernand Pouillon. Aix en Provence, France: Cercle d'Etude Architecturale.

Sayen, C. (2014). I'Architecture par Fernand Pouillon. Toulouse, France: Transversales. 
Tehami, M. and Anouche, K. (2017). "Urban planning as the first step of architecture" a response to the mass housing issue and the quality of its interior landscape: The case study of Pouillon's housing estate "Diar El Mahçoul" in Algiers. ZARCH Journal of Interdisciplinary Studies in Architecture and Urbanism, 8: 146-152. https://doi.org/10.26754/ojs_zarch/zarch.201782152.

van der Rohe, L.M. (1996). Réflexion Sur L'art de Bâtir. Paris: Le Moniteur.

Wellhoff, F. and Perignon, J.M. (2010). Influence sur la qualité architecturale de la réglementation issue des documents d'urbanisme. Report CGEDD No. 006562-01. La Défense, France: Conseil Général de l'Environnement et du Developpement Durable. Available at: http://cgedd.documentation. developpement-durable.gouv.fr/documents/cgedd/006562-01_rapport. pdf. 